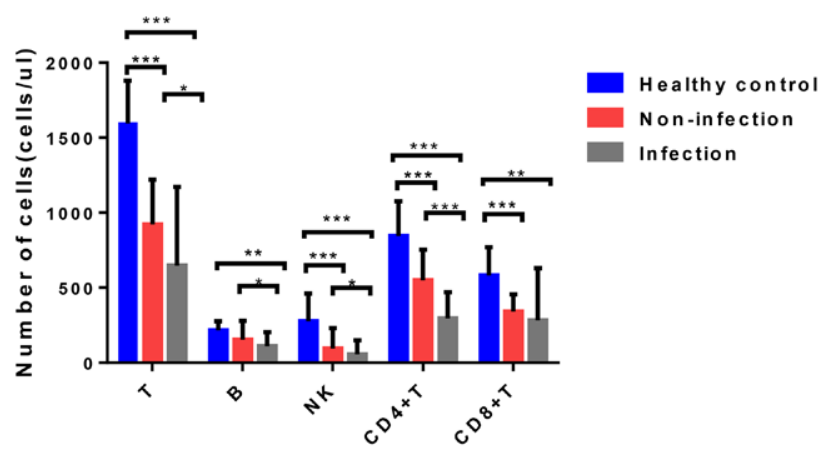

B

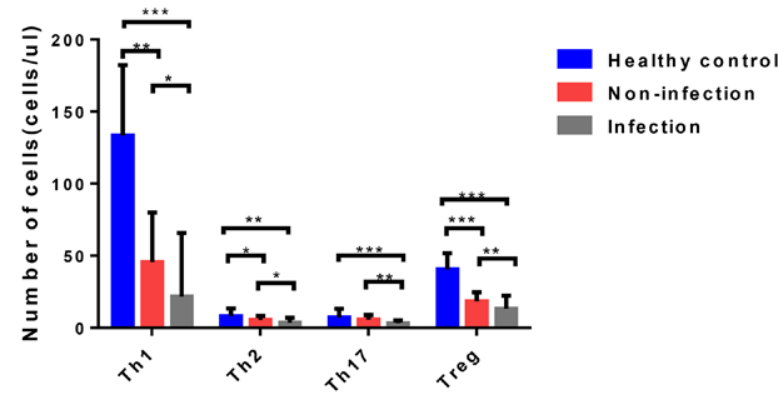

Figure. Absolute numbers of peripheral lymphocyte subsets between healthy controls and patients were assessed by fow cytometry using oneplatform method. PM/DM infection group $(n=34), P M / D M n$ non- infection group $(n=31)$ and healthy control group $(n=20) .\left({ }^{*} p<0.05\right.$, $\left.{ }^{\star *} p<0.01,{ }^{\star \star *} p<0.001\right)$

Disclosure of Interests: None declared

DOI: 10.1136/annrheumdis-2020-eular.5163

\section{AB0631 THE CLINICAL CHARACTERISTICS OF SYSTEMIC SCLEROSIS WITH LUNG CANCER: DATA FROM SINGLE CENTER IN CHINA}

H. Zhong ${ }^{1}$, J. Zhou ${ }^{1}$, S. Zhang ${ }^{1}$, Y. Xu ${ }^{2}$, Y. Hou ${ }^{1}$, M. Li ${ }^{1}$, D. Xu ${ }^{1}$, M. Wang ${ }^{2}$, X. Zeng ${ }^{1}{ }^{1}$ Peking Union Medical College Hospital, Chinese Academy of Medical Sciences, Department of Rheumatology, Beijing, China; ${ }^{2}$ Peking Union Medical College Hospital, Chinese Academy of Medical Sciences, Department of Respiration, Beijing, China

Background: Malignant neoplasms is the second most common non-SSc associated cause of death in SSc patients, only second to infection. And among all the neoplasms, lung cancers are the most common, which is in the urgent need of attention from clinicians.

Objectives: To analyze the clinical features of patients of SSc with lung cancer. Methods: Medical records of inpatients admitted in Peking Union Medical College Hospital from March 1992 to December 2018, were collected and analyzed, including the clinical manifestation, laboratory data, radiological images, pathology. SSc patients without lung cancer during the same period, matched by age and gender, were selected as the controls.

Results: Nineteen SSc patients with complete medical records were identified, with $17(89.5 \%)$ females and $2(10.5 \%)$ males. The mean age of SSc onset was $37.8 \pm 12.0)$ years old and of lung cancer diagnosis was $(54.4 \pm 10.2)$ years old. One $(5.3 \%)$ had a smoking history. Eight $(42.1 \%)$ patients had family history of cancer, which was significantly higher than those without lung cancer (4 patients, 5.3\%, $\mathrm{P}<0.001$ ). The proportion of limited cutaneous SSc (ICSSc) were $63.2 \%$ among these patients, and $18(94.7 \%)$ had interstitial lung disease (ILD), the difference between the two groups was not statistically significant $(P=0.259$ and 0.051 , respectively). All ILD was diagnosed before the onset of lung cancer, with a median interval of 9.2 (range 1.6-28.1) years. SSc patients with lung cancer had less myositis than control group ( $0 \%$ vs. $27.6 \%, P=0.032$ ), yet no significant differences were identified in Raynaud's syndrome, esophageal involvement, digital ulcers, pulmonary hypertension, telangiectasia and arthritis. All patients developed lung cancer after the diagnosis of SSc, with a median interval 10.5 (range 2.0-36.2) years. In most of them(18, 94.7\%), lung cancer happened after at least 6 years of SSc onset. Newly happened cough (9 patients), worsening decrease in activity endurance (3), chest pain (2), hemoptysis (2), nodes in lung through regular CT scans (3) were the first presentations of lung cancer. Ten(62.5\%) neoplasms developed in the lower lobes of the lung, while 3 was in the upper lobes, one in the lingual lobe, and one in the left pulmonary hilum, and 3 were unknown. The median survival of the case group were 31.4 years, while the median survival of the control group was not reached. Eight patients tested EGFR gene mutation or ALK gene rearrangement, and only 2 were positive.

Conclusion: It is not uncommon that SSc could be concomitant with lung cancer, especially for those with long disease duration and family history of malignancy. Due to the subtle onset of lung cancer, clinicians should pay attention to it during clinical practice.

References:

[1] Hu S et al. Arthritis Res Ther, 2018, 20:235.

[2] Steen VD, Ann Rheum Dis, 2007, 66:940-944.

[3] Tyndall AJ et al. Ann Rheum Dis, 2010, 69:1809-1815.

[4] Compton CC et al. AJCC Cancer Staging Atlas [M].7th ed. New York:Springer 2012:311-328.

[5] Detterbeck FC et al. Chest, 2016, 1:193-203.

[6] Kuo CF et al. J Rheumatol, 2012, 41:44-49.

[7] Nishioka K et al. J Dermatol, 1996, 23:677-682.

[8] Ling Z, et al. 2016, 10:238-241.

[9] Heist RS et al. J Thorac Oncol, 2012, 7:1775-1780.

[10] Kim HR et al. J Clin Oncol, 2013, 31:731-737.

[11] Igusa T et al. Ann Rheum Dis, 2018, 77:1179-1186.

[12] Hill CL et al. Lancet, 2001, 357:96-100.

[13] Pontifex EK et al. Ann Rheum Dis, 2007, 66:551-553.

[14] Thun MJ et al. N Engl J Med, 2013, 368:351-364.

Disclosure of Interests: Hui Zhong: None declared, Jiaxin Zhou: None declared, Shangzhu Zhang: None declared, Yan Xu: None declared, Yong Hou: None declared, Mengtao Li: None declared, Dong Xu: None declared, Mengzhao Wang: None declared, Xiaofeng Zeng Consultant of: MSD Pharmaceuticals DOI: 10.1136/annrheumdis-2020-eular.3423

\section{Spondyloarthritis - treatment}

\begin{tabular}{l|l}
\hline AB0632 & EFFECTIVENESS OF ETANERCEPT BIOSIMILARS \\
IN REACTIVE ARTHRITIS: RETROSPECTIVE CASE \\
CONTROL
\end{tabular}

S. Ahmed ${ }^{1}$, P. Padhan ${ }^{1} .{ }^{1}$ Kalinga Institute of Medical Sciences (KIMS), Bhubaneswar, India

Background: There is a paucity of evidence based therapies for reactive arthritis $(\operatorname{ReA})$. Data is limited for anti-TNF drugs usage [Table 1] with even less data on biosimilars.

Table 1. Anti-TNF use in reactive arthritis

\begin{tabular}{|c|c|c|c|c|}
\hline Place (year) & Anti-TNF & $\mathrm{N}$ & Outcomes & Remarks \\
\hline $\begin{array}{l}\text { Pennsylvania, } \\
\text { USA (2005) }\end{array}$ & Etanercept & 16 & $\begin{array}{l}10 \text { completed trial: } 9 \\
\text { responders }\end{array}$ & $\begin{array}{l}\text { Synovial histology } \\
\text { improvement but } \\
\text { not normalized }\end{array}$ \\
\hline $\begin{array}{l}\text { Strasbourg, } \\
\text { France (2011) }\end{array}$ & $\begin{array}{l}\text { Infliximab(5) } \\
\text { Etanercept(4) } \\
\text { Adalimumab(1) }\end{array}$ & 10 & $\begin{array}{l}\text { Rapidly effective in } 9 \\
\text { patients }(90 \%) \\
5 \text { had DFR }\end{array}$ & $\begin{array}{l}\text { Relapses responded } \\
\text { to re- initiation }\end{array}$ \\
\hline $\begin{array}{l}\text { Besançon, } \\
\text { France (2016) }\end{array}$ & $\begin{array}{l}\text { Etanercept (9) infliximab } \\
\text { (3) Adalimumab(3) }\end{array}$ & 15 & 5 had DFR & $\begin{array}{l}9 \text { developed chronic } \\
\text { SpA }\end{array}$ \\
\hline $\begin{array}{l}\text { Delhi, India } \\
\qquad(2019)\end{array}$ & $\begin{array}{l}\text { Infliximab(10), } \\
\text { Adalimumab(3) } \\
\text { Etanercept(1) }\end{array}$ & 9 & $\begin{array}{l}\text { At median of } 3.5 \\
\text { months: } 4 \text { had } \\
\text { remission, } 3 \text { relapse, } \\
1 \text { adverse reaction }\end{array}$ & $\begin{array}{l}\text { Biologicals were not } \\
\text { given regularly }\end{array}$ \\
\hline Current study & Etanercept biosimilars & 10 & $\begin{array}{l}\text { At median } 7 \text { months: } \\
6 \text { had DFR }\end{array}$ & $\begin{array}{l}\text { All patients } \\
\text { responded }\end{array}$ \\
\hline
\end{tabular}

DFR: drug free remission

Objectives: To find out the outcomes of etanercept biosimilars (ETN-b) use in $\operatorname{ReA}$

Methods: A retrospective review of patients meeting the Braun criteria ${ }^{5}$ for probable ReA helped identify patients on ETN-b. Patients with less than 1 year follow-up and those who had received less than 5 doses of ETN were excluded. Biological naïve patients who had completed at least 1 year follow-up were included as controls. Baseline and current status was compared between these two groups. Results: Of 94 identified ReA patients, 11(11.7\%) had received ETN-b and 10 met the case definition. Five each had received one of two ETN-b. 30 were available as controls. All cases had been documented as refractory ReA. Amongst cases, 7 patients had resolution of $\mathrm{ReA} ; 2$ had relapsing courses and 1 persistent arthritis. Four were in remission off all drugs. Controls has similar proportions [Table 2]. There were no infections or adverse effects recorded during follow-up. 
Table 2. Comparison between etanercept group and biological naïve groups

\begin{tabular}{|c|c|c|c|}
\hline & $\begin{array}{l}\text { Etanercept } \\
\text { group } \\
(n=10)\end{array}$ & $\begin{array}{l}\text { Non-etanercept } \\
\text { group } \\
(n=30)\end{array}$ & $\begin{array}{c}\text { Non parametric } \\
\text { tests of } \\
\text { significance }\end{array}$ \\
\hline Age at presentation (years) & $27(17.2-34.2)$ & $25(19-34.2)$ & NS \\
\hline Males & $10(100 \%)$ & $22(55 \%)$ & NS \\
\hline Follow-up (months) & $27(15-71.7)$ & $27(15-79.5)$ & NS \\
\hline Preceding infection & $\begin{array}{c}\text { Diarrhoea }=6 \\
\text { UTI }=4\end{array}$ & $\begin{array}{c}\text { Diarrhoea }=23 \\
\text { UTI }=7\end{array}$ & NS \\
\hline Inflammatory backache & 3 & 11 & NS \\
\hline Small joint involvement & 4 & 11 & NS \\
\hline $\begin{array}{l}\text { Monoarticular/ oligoarticular/ } \\
\text { polyarticular }\end{array}$ & $3 / 3 / 4$ & $10 / 8 / 12$ & NS \\
\hline Average intra-articular injections & 1.9 & 0.3 & NS \\
\hline Sulfasalazine & 9 & 22 & NS \\
\hline Methotrexate & 1 & 1 & NS \\
\hline Disease outcome & $\begin{array}{l}\text { Resolved }=7 \\
\text { Relapsing }=2 \\
\text { Persistent }=1\end{array}$ & $\begin{array}{l}\text { Resolved }=19 \\
\text { Relapsing }=9 \\
\text { Persistent }=2\end{array}$ & NS \\
\hline Drug free remission & $4(40 \%)$ & $12(40 \%)$ & NS \\
\hline BASDAI at last follow-up & $0.3(0-0.8)$ & $0(0-1.4)$ & NS \\
\hline HAQ-DI at last follow-up & $0(0-0.15)$ & $0.05(0-0.3)$ & NS \\
\hline
\end{tabular}

BASDAI: Bath Ankylosing Spondylitis Disease Activity Index; HAQ-DI: Health Assessment Questionnaire Disability Index; NS: not significant

Conclusion: All 10 patients responded. 40\% achieved drug free remission. Thus, ETN-b appear safe and effective for ReA refractory to conventional therapy. References:

[1] Flagg SD, Meador R, et al. Decreased pain and synovial inflammation after etanercept therapy in patients with reactive and undifferentiated arthritis: an open-label trial. Arthritis Rheum. 2005;53(4):613-7

[2] Meyer A, Chatelus E, et al. Safety and efficacy of anti-tumor necrosis factor a therapy in ten patients with recent-onset refractory reactive arthritis. Arthritis Rheum. 2011 May;63(5):1274-80

[3] Brinster A, Guillot X, et al. SAT0387 Anti Tnf Treatment of Reactive Arthritis. A Monocentric Experience. Ann Rheum Dis 2016;75:808

[4] Gupta V, Mohta P, et al. A retrospective case series of 12 patients with chronic reactive arthritis with emphasis on treatment outcome with biologics. Indian J Dermatol Venereol Leprol. 2019 [in print]

[5] Braun J, Kingsley G, et al. On the difficulties of establishing a consensus on the definition of and diagnostic investigations for reactive arthritis. 1999. J Rheumatol. 2000;27(9):2185-92

Disclosure of Interests: None declared

DOI: 10.1136/annrheumdis-2020-eular.295

\section{AB0633 REAL WORLD EXPERIENCE OF THE IMPACT OF SECUKINUMAB ON DISEASE ACTIVITY AND FATIGUE IN PATIENTS WITH ANKYLOSING SPONDYLITIS}

S. Batool' ${ }^{1}$ S. Bawa' ${ }^{1}$ Gartnavel General Hospital, Rheumatology, Glasgow, United Kingdom

Background: Fatigue is one of the most commonly reported symptom of ankylosing spondylitis (AS). It impacts functional ability, quality of life, and ability to maintain employment ${ }^{1}$. Secukinumab, a fully human monoclonal IgG1 antibody that neutralizes IL-17A, has shown significant and sustained improvement in the signs and symptoms of active AS in the MEASURE 2 study $^{2}$. It has also shown to improve fatigue scores. Despite this, the published literature on real life experience is scarce. We report our experience of Secukinumab use at Gartnavel General Hospital, Glasgow, UK.

Objectives: We performed a retrospective review to assess the response of our AS patients to Secukinumab. We also reviewed the impact of treatment on fatigue.

Methods: AS patients commenced on Secukinumab 150mg subcutaneously from mid-2016 to September 2019 were identified using the clinical records on our database. Response using Bath AS disease activity index (BASDAI) and Bath AS function index (BASFI) were recorded. Impact on fatigue and pain was measured using single-item fatigue and pain visual analogue scale (VAS) within the BASDAI questionnaire.

Results: 30 AS patients, 11 anti-TNF naïve and 19 anti-TNF inadequate responders (IR), on Secukinumab were identified. Retention rate was $76.66 \%$ (23/30). Sustained improvement was observed across all outcome measures over 3.5 years. Fatigue and pain improvement were somewhat lower than expected but did show slow improvement. Responses were greater in anti-TNF naïve patients. There was no significant difference in response between smokers $(33.34 \%, 10 / 30)$ and non-smokers $(36.67 \%, 11 / 30)$. There were 4 patients with inflammatory bowel disease, none of whom flared. No new safety signals were identified.

Table. Clinical response to Secukinumab in patients with active AS

\begin{tabular}{lcccccccc}
\hline Time & BASADI & \multicolumn{3}{c}{ BASFI } & \multicolumn{3}{c}{ Fatigue } & \multicolumn{3}{c}{ AS pain } \\
\hline & Mean & \%change & Mean & \%change & Mean & \%change & Mean & \%change \\
\hline Baseline & 7.09 & & 7.3 & & 7.6 & & 7.99 & \\
3M & 6.71 & $-5 \%$ & 7.24 & $-8 \%$ & 6.9 & $-9 \%$ & 6.89 & $-14 \%$ \\
$6 \mathrm{M}$ & 5.4 & $-24 \%$ & 5.8 & $-20 \%$ & 6.29 & $-17 \%$ & 6.06 & $-24 \%$ \\
$9 \mathrm{M}$ & 6.01 & $-15 \%$ & 6.56 & $-10 \%$ & 6.41 & $-16 \%$ & 6.1 & $-24 \%$ \\
$12 \mathrm{M}$ & 5.04 & $-29 \%$ & 5.42 & $-26 \%$ & 6.35 & $-16 \%$ & 5.55 & $-30 \%$ \\
$18 \mathrm{M}$ & 4.98 & $-30 \%$ & 3.73 & $-49 \%$ & 6.38 & $-16 \%$ & 4.91 & $-38 \%$ \\
$24 \mathrm{M}$ & 5.52 & $-22 \%$ & 5.72 & $-22 \%$ & 6.79 & $-11 \%$ & 5.6 & $-30 \%$ \\
$\%$ Change from & Anti-TNF & Anti-TNF & Anti-TNF & Anti-TNF & Anti-TNF & Anti-TNF & Anti-TNF Anti-TNF \\
baseline & naïve & IR & naïve & IR & naïve & IR & naïve & IR \\
3M & $-37 \%$ & $-9 \%$ & $-44 \%$ & $6 \%$ & $-10 \%$ & $-14 \%$ & $-53 \%$ & $-14 \%$ \\
$6 \mathrm{M}$ & $-34 \%$ & $-27 \%$ & $-38 \%$ & $-29 \%$ & $-28 \%$ & $-6 \%$ & $-43 \%$ & $-6 \%$ \\
$9 \mathrm{M}$ & $-27 \%$ & $-4 \%$ & $-30 \%$ & $1 \%$ & $-23 \%$ & $-6 \%$ & $-41 \%$ & $-6 \%$ \\
$12 \mathrm{M}$ & $-41 \%$ & $-22 \%$ & $-31 \%$ & $-29 \%$ & $-31 \%$ & $0 \%$ & $-44 \%$ & $0 \%$ \\
$18 \mathrm{M}$ & $-32 \%$ & $-11 \%$ & $-57 \%$ & $-22 \%$ & $-35 \%$ & $5 \%$ & $-34 \%$ & $5 \%$ \\
$24 \mathrm{M}$ & $-26 \%$ & $-12 \%$ & $-32 \%$ & $-1 \%$ & $-16 \%$ & $3 \%$ & $-32 \%$ & $3 \%$ \\
\hline
\end{tabular}

There were $<3$ patients in $>2$ years follow up group therefore results were omitted from analysis

Conclusion: In our real-life cohort of AS patients, significant improvement was seen over 3.5 years in both BASDAI and BASFI. Fatigue was significantly improved in anti-TNF naïve group, but results were disappointing in anti-TNF IR group. This may be explained by the fact that there are older patients with established disease and background degenerative changes in anti-TNF IR group. Although fatigue data had slightly discordant results compared with the MEASURE 2 study $^{2}$, considering the use of single item VAS rather than multidimensional measures such as FACEIT fatigue scale, clear improvement has been observed.

References:

[1] E. E. Schneeberger, M. F. Marengo, F. Dal Pra, J. A. Maldonado Cocco, and G. Citera, "Fatigue assessment and its impact in the quality of life of patients with ankylosing spondylitis," Clin Rheumatol, vol. 34, no. 3, pp. 497-501, 2015.

[2] H. Marzo-Ortega, J. Sieper, A. Kivitz, R. Blanco, M. Cohen, R. Martin, A. Readie, H. B. Richards, and B. Porter, (2017) 'Secukinumab and Sustained Improvement in Signs and Symptoms of Patients With Active Ankylosing Spondylitis Through Two Years: Results From a Phase III Study', Arthritis Care \& Research, Vol. 69, No. 7, July 2017,(DOI 10.1002/acr.23233), pp. 1020-1029.

Acknowledgments: S. Kerr, K. Anderson and Rheumatology department, Gartnavel General Hospital, Glasgow, UK

Disclosure of Interests: None declared

DOI: 10.1136/annrheumdis-2020-eular.4312

\section{AB0634 BUDGET IMPACT ANALYSIS OF BIOLOGICAL THERAPY COMPARED TO CONVENTIONAL SPONDYLOARTHRITIS TREATMENT, IN A FOURTH LEVEL HOSPITAL IN BOGOTA COLOMBIA}

J. M. Bello-Gualtero ${ }^{1}$, O. J. Calixto ${ }^{2}$, G. Salguedo ${ }^{2}$, Y. M. Chamorro-Melo ${ }^{1}$, C. A. Camargo Rodríguez ${ }^{3}$, H. Quitian Ruiz ${ }^{3}$, A. Beltrán ${ }^{3}$, G. Saavedra ${ }^{3}$. ${ }^{1}$ Hospital Militar Central, Rheumatology and Immunology Service, Bogota, Colombia; ${ }^{2}$ Universidad Militar Nueva Granada, Internal Medicine, Bogota, Colombia; ${ }^{3}$ Hospital Militar Central, Scientific Research Unit, Bogota, Colombia

Background: Spondyloarthritis refers to a family of diseases, of which ankylosing spondylitis and non-radiographic axial spondyloarthritis are responsible for axial impairment. Previously, the only treatment available were NSAIDs, which control activity and stop radiological progression, but at the expense of increased adverse effects, such as cardiovascular risk, dyspepsia and chronic renal failure. For the past 2 decades, biological therapy has been available, which means an increase in care costs.

Objectives: The objective of this study is to perform a budget impact analysis of biologic therapy.

Methods: To do a budget impact analysis from the perspective of the payer, comparing biological therapy with coventional therapy for the treatment of spondyloarthritis. Demographic characterization of the population attended at the Central Military Hospital. Time horizon from 2012 to 2018, taking the activity count according to the hospital's billing and the prices of the activities of the state body SISMED. Exchange rates at the end of 2018.

Results: The patients attended were 117 , mostly men $(63,25 \%)$, average age 46,4 years (SD 13), with disease diagnosis time of 9,8 years (SD 9, 6). In the budget impact analysis, it is observed that $25 \%$ of patients were on DMARDs 